[DOI: 10.24214/jecet.A.10.1.03346.]

Juurnal of Enviranmental Science, Computer Science and Engineering \& Technology

An International Peer Review E-3 Journal of Sciences and Technology

Available online at www.jecet.org

Section A: Environmental Science

Research Article

\title{
A Report on a Practical Survey of Karu Abattoir and Review of Factors Influencing Quality Hides and Skins Production.
}

\author{
${ }^{1,2}$ Okwuolise, I.M., ${ }^{1 *}$ Onukak, I.E., and ${ }^{1}$ Oparah E.N.
}

${ }^{1}$ Nigerian Institute of Leather and Science Technology, Zaria, Nigeria

${ }^{2}$ Department of Veterinary Public Health and Preventive Medicine, Ahmadu Bello University, Zaria, Nigeria

Received: 10 January 2021; Revised: 08 February 2021; Accepted: 15 February 2021

\begin{abstract}
A Two (2) weeks practical survey of Karu Abattoir was carried out to determine the state of facilities and management system obtainable to ensuring regulated practices and better production of quality hides and skins. The abattoir is situated in a boundary area of the Federal Capital Territory (FCT) and Nasarawa State of Nigeria. It is presently in the middle of a busy part of the town which houses residential areas, schools and various business outfits and the road network leading thro and fro the abattoir is accessible and in good state. The abattoir facilities including the available lairage, slaughter, condemned meat rooms, hides and skins preservation room, veterinary laboratory, water supply system, waste discharge system and the hoisting equipment where assessed. The current man power, and the management system adopted were also observed. The following observations were made; The site lacked proper sanitation and hygiene standards were not properly adhered to. Handling, proper preservation and drainage to manage waste water were also a challenge. Workers were not properly kitted with boots, aprons, hand gloves and scarf. However, flies and offensive odour were minimal because the premise was fumigated on daily basis (putting Hazard Analysis Critical Control Point, HACCP into consideration) and
\end{abstract}


sources of maggots and odour were identified and arrested using de-odorizing agents and readily available chemicals. It was also observed that, the management order in the abattoir was from, The Government-The Livestock Director-The Manager (a Veterinarian)-The Assistant Manager-The Meat Inspectors. Animal by-products such as bones, horns, hooves, blood where duly utilised. The Hides and skins were cured and taken to Kano and sold on request to the Tanneries. The nearby stream served as a drainage channel for the abattoir and we recommend that the management of the Federal Capital Territory Administration should provide adequate source of waste collection point for treatment before discharging it into the nearby stream to protect the public health. Other recommendations are; to increase the capacity of the site in terms of labor and structure to meet rising demands as the population of the area have increased over time. Optimal implementation of National Leather and Leather Products Policy is recommended. In general, factors such as animal husbandry and disease management, slaughter facilities and practices, handling and preservation methods as observed in Karu abattoir, may affect the quality of hides and skin which are leather economic source if serious attention are not taken to providing suitable services, facilities and infrastructure.

Keywords: Abattoir, tanneries, slaughter, lairage and hoisting, hides and skins, leather.

\section{INTRODUCTION}

It is common to an average African to think and assume that Abattoir activities only involve the slaughtering of animals to be sold for human consumption. This definition may best describe a slaughter slab but too superficial for abattoir. Abattoir is usually located in a secluded location or premises away from the township or urban areas in most Nigerian settings.

The etymology of the word Abattoir originated from the French root word "Abattre" meaning to fell or to strike down ${ }^{[1]}$ Otherwise, Abattoir has been defined as an approved and registered premise by the controlling authorities for hygienic slaughtering and inspection, processing and effective preservation and storage of meat for human consumptions, hides and skin preservation for leather processing ${ }^{[2,3]}$.

A standard abattoir is made up of the following units; Animal inspection unit, hoisting facility, slaughter hall, a room for condemned meat and offal and Veterinary laboratory. Others include; Emergency slaughter room, borehole facility, efficient sewage for waste collection, Hides and skin curing room etc.

Some abattoir practices which result in low quality of produce includes, force fasting, inhumane transportation, poor stunning, slaughter and flaying techniques, lack of proper sanitation, preservation and storage systems. There are standard best practices to ensure quality produce suitable for direct consumptions and further processing/value addition. Authorised regulatory personnel/bodies must supervise and ensure adherence to standards and best practices ${ }^{[4]}$.

The standards of construction, facilities and practises of general abattoirs, pursuant to the provision of the Abattoirs law is as follows;

Abattoirs Shall have stockyard facilities (lairage), ante-mortem inspection facilities, processing room, cooling installations, inspection room, disinfection facilities, segregation facilities, waste treatment facilities and meat (including viscera) used for human consumption transaction area. ${ }^{[5]}$. Table 1 , contains the summary of control points, construction/facilities and inspection requirements. 


\section{LITERATURE REVIEW}

\subsection{Basic Requirements for the Establishment of Standard Abattoirs}

The standards of construction, facilities and practises of general abattoirs, pursuant to the provision of the Abattoirs law is as follows;

Abattoirs Shall have stockyard facilities (lairage), ante-mortem inspection facilities, processing room, cooling installations, inspection room, disinfection facilities, segregation facilities, waste treatment facilities and meat (including viscera) used for human consumption transaction area. ${ }^{[5]}$. Table 1, contains the summary of control points, construction/facilities and inspection requirements.

Table 1: Basic Requirements for the Establishment of Standard Abattoirs

\begin{tabular}{|c|c|c|c|}
\hline & Control Points & Requirements & Inspections \\
\hline & $\begin{array}{l}\text { License for } \\
\text { establishment of } \\
\text { abattoir, lairage and } \\
\text { slaughtering. }\end{array}$ & $\begin{array}{l}\text { Abattoir, lairage and slaughtering shall be } \\
\text { registered and permitted by the Department of } \\
\text { Livestock Development (DLD). }\end{array}$ & $\begin{array}{l}\text { Inspection of documents } \\
\text { and license }\end{array}$ \\
\hline & Location & $\begin{array}{l}\text { 2.1 Do not locate nearby the community. } \\
\text { 2.2 Prevent contamination of hazardous } \\
\text { substances from agriculture and } \\
\text { manufacturing industry. }\end{array}$ & Visual inspection \\
\hline & Lairage & $\begin{array}{l}\text { 3.1 Lairage area shall have adequate space for } \\
\text { all animals held for slaughtering. } \\
\text { 3.2 There is a separated area for sick or } \\
\text { suspected sick animal } \\
\text { 3.3 Construction materials shall be strong and } \\
\text { can protect the animals from unsuitable } \\
\text { environment. } \\
\text { 3.4 Lairage area shall have the waste water } \\
\text { drainage. }\end{array}$ & Visual inspection \\
\hline & $\begin{array}{l}\text { The building of } \\
\text { abattoir }\end{array}$ & $\begin{array}{l}\text { 4.1 Construction materials for both indoor and } \\
\text { outdoor shall be strong and durable, not } \\
\text { harmful to animals, easy for cleaning and } \\
\text { can protect the animals from unsuitable } \\
\text { environment. } \\
\text { 4.2 The area for live animals shall be separated } \\
\text { from the operating area. } \\
\text { 4.3 The dirty and clean zones shall be } \\
\text { separated. } \\
\text { 4.4 The edible products operating area shall be } \\
\text { separated from the area of inedible } \\
\text { products. } \\
\text { 4.5 There shall be systems in place for public } \\
\text { utility cleaning and waste water drainage. } \\
\text { 4.6 The temperature for specific operation room } \\
\text { can be controlled. }\end{array}$ & Visual inspection \\
\hline & $\begin{array}{l}\text { Equipment, } \\
\text { machinery and } \\
\text { utensils }\end{array}$ & $\begin{array}{l}\text { 5.1 They shall be able to be cleaned and } \\
\text { Disinfected Visual inspection, if there is the } \\
\text { risk, the products shall be analysed. } 3 \text { TAS } \\
9008-2006 \\
\text { 5.2 They shall not be contaminated with the } \\
\text { heavy metal and other hazards. }\end{array}$ & \\
\hline
\end{tabular}




\begin{tabular}{|c|c|c|}
\hline 6. Chilling room & $\begin{array}{l}\text { The temperature of carcass shall be } \\
\text { controlled to maintain core temperature } \\
\text { between } 4 \text { and } 10^{\circ} \mathrm{C} \text {. }\end{array}$ & Temperature monitoring \\
\hline $\begin{array}{l}\text { 7. Waste water } \\
\text { treatment system }\end{array}$ & $\begin{array}{l}\text { Waste water treatment system shall be in } \\
\text { place in compliance with relevant laws. }\end{array}$ & Visual inspection \\
\hline $\begin{array}{l}\text { 8. Transportation and } \\
\text { movement of live } \\
\text { animals }\end{array}$ & $\begin{array}{l}\text { 8.1 The practices are considered with the } \\
\text { animal welfare. } \\
\text { 8.2 Transportation and movement of animal } \\
\text { shall be approved by Department of } \\
\text { Livestock Development. } \\
\text { 8.3 The report of farm animal examination shall } \\
\text { be available. }\end{array}$ & $\begin{array}{l}\text { Visual inspection and } \\
\text { report review }\end{array}$ \\
\hline 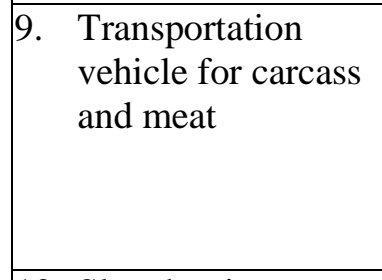 & $\begin{array}{l}\text { 9.1 The vehicle shall be specially designed for } \\
\text { meat transportation. } \\
\text { 9.2 The container shall have temperature } \\
\text { control system. } \\
\text { 9.3 The inside and outside of container shall be } \\
\text { washable. }\end{array}$ & $\begin{array}{l}\text { Visual inspection and } \\
\text { temperature monitoring }\end{array}$ \\
\hline 10. Slaughtering & $\begin{array}{l}\text { 10.1 Humane slaughtering } \\
\text { 10.2 Animal shall be rendered completely } \\
\text { unconscious prior to slaughtering The } \\
\text { suitable method shall be applied to each } \\
\text { animal species in accordance with animal } \\
\text { welfare, except the religious practices. }\end{array}$ & Visual inspection \\
\hline $\begin{array}{l}\text { 11. Ante-mortem and } \\
\text { post-mortem } \\
\text { inspections }\end{array}$ & $\begin{array}{l}\text { There are assigned officers who have the } \\
\text { responsibility to examine the animals before and } \\
\text { after slaughtering. }\end{array}$ & $\begin{array}{l}\text { Review the report of } \\
\text { ante-mortem and } \\
\text { postmortem inspections. }\end{array}$ \\
\hline $\begin{array}{l}\text { 12. Management and } \\
\text { hygienic control }\end{array}$ & $\begin{array}{l}\text { 12.1 There shall be systems in place for pest } \\
\text { control and management of waste } \\
\text { products. } \\
\text { 12.2 Workers shall have physical examination } \\
\text { at least once a year. }\end{array}$ & $\begin{array}{l}\text { Visual inspection, review } \\
\text { related documents, if } \\
\text { there is the risk, the } \\
\text { products shall be } \\
\text { analysed. }\end{array}$ \\
\hline 13. Recording & $\begin{array}{l}\text { 13.1 Animal health status before and after } \\
\text { slaughtering shall be recorded } \\
\text { 13.2 The hygienic status shall be verified and } \\
\text { reported before the operation. }\end{array}$ & Review of the records \\
\hline
\end{tabular}

Source: ${ }^{[5]}$

\subsection{Factors influencing quality hides and skins production:}

Grade' is a term used in determining the quality of hides and skins in leather industry. A grade roughly indicates the fitness of a hide or skin for a specific use. Grades are defined in terms of the presence or absence of certain types of defects on the hides and skins. However, perception about those defects and the application for grading hides and skins may vary at different stages of the production and processing chain and between different operators within a stage. These problems notwithstanding, quality remains the main factor determining the market potential of hides and skins ${ }^{[6]}$. 
Throughout the production chain, factors including animal husbandry and disease management, slaughter facilities and practices, handling and preservation methods may affect the quality of hides and skin.

2.2.1. Animal Husbandry: A greater portion of livestock available for harvesting of hides and skins are local breeds raised in pastoral systems by nomadic and semi-nomadic herders and a small proportion are raised by small-holder crop-livestock mixed farmers. Consequently, the quality of hides and skins from the animal are generally poor due to poor nutrition, not culling animals until old age, damages on hides and skins caused by scratches and horn rakes, branding and tick bites and other diseases ${ }^{[6]}$.

2.2.2. Nutritional deficiencies: Extinction, High death rates, Nutritional deficiencies are major causes of insufficient breed of livestock available in the country. Nutritional deficiencies are usually nonspecific and are often the result of low plane nutrition, insufficient intake of feed energy is the main cause of retarded growth. Hides and skins from areas where feeds available for the animals are inadequate usually bear tell-tale quality characteristics. The hides are normally of small size, mainly lights and mediums with thin substance. The post-mortem preparation of hides and skins is generally poor so that these materials result in high lime-loss rejects percentages when processed in the tannery ${ }^{[7]}$.

Nigerian Hides and Skins are characterized with majorly hides and skins from Cattle, Sheep and Goat. However, the pastoral system of farming has not improved over the years as cattle, sheep and goat are being imported into the country from the neighboring countries like Niger, Cameroon and Chad.

2.2.3. Bio-Generic Breeding: There is urgent need for an improved animal husbandry system and exotic breeding of major livestock for improvement in quantity and quality hides and skin production. Development of higher animal and livestock breeds that will tolerate adverse weather conditions and adapt to peculiar effects of climate changes will produce better quality hides and skins for the leather industry.

2.2.4. Mechanical Damages: Damages caused to the hides and skins under pastoral and small holder husbandry conditions while the animal is alive, is mostly attributed to various types of mechanical actions and is classified as mechanical damage. Loss of value due to these types of damages is perceived by stakeholders in the industry to be around $40 \%$ of the total value of hides and skins for Africa in general. The defects are identified according to the type of damage caused or by the causative agent ${ }^{[6]}$.

2.2.5. Scratches and horn rakes: Scratches are amongst the most common mechanical damages found among Hides. This is because most of the livestock is concentrated in areas of open or areas with fairly dry environment where thorny bushes are found. Multiple scratches are therefore quite common. Scratches give leather an unaesthetic appearance and if deep, cause considerable loss of tear strength especially on skins. The quality is also degraded as tanners try to obscure the faults on the grains by embossing or printing, which also increase processing costs. Consequently, the raw materials fetch lower prices ${ }^{[8]}$.

On cattle hides horn rakes are a general problem as animal husbandry practices in these countries discourage dehorning. Therefore, cattle injure the hides mostly in crushes, in fights or during transportation. In some cases, the damage is quite serious as the wound is generally deep. Another type of serious damage is caused in many countries in goads, and other pointed instruments, which produce actual punctures, usually in the most valuable part of the hide, but the practice is not common in the Sudan ${ }^{[6]}$.

2.1.6. Branding: The widespread and indiscriminate practice of branding cattle with hot irons causes high losses in the hide and leather industry. Anything from 10-40 percent of the value of the hide is 
lost by the unsightly and irreparable damage caused by branding ${ }^{[8]}$. The practice of branding is common due to prevalence of cattle rustling and farmers use prominent branding in order to identify their animals. There are also pastoral tribes who use branding as treatment method for certain diseases especially by applying hot irons on glands. Unfortunately, most branding is done on areas of hides, e.g. on the back and rumps, which have high value ${ }^{[9]}$.

2.1.7. Tick Bites: Infestation of ticks on livestock not only causes damage to hides and skins but also spread of livestock diseases, as ticks are important vectors of tick-borne diseases. Unfortunately, in many African countries animal husbandry measures for controlling ticks are expensive due to the use of chemicals (acaricides) and therefore a lot of farmers leave their animals unprotected from ticks.

One of the major causes of down grading of hides and skins is attributed to tick-marks. These parasites attach themselves on the hides and skins in order to feed on the blood of the host animal. When in unfed state, they are usually flat but when engorged with blood, they become almost spherical.

Heavy infestation of these parasites can cause substantial loss of blood from the host animal making it weaker. The ticks are also major disease vectors and cause transmission of diseases e.g. Streptothicosis and Nodular Dermatofilosis.

More so, specifically for the hides and skins industry, they damage the skin in areas where they attach themselves which become inflamed and sometimes permit entry of other parasites e.g. screw-worms and various microbes. The healing of areas of attachment normally leaves behind pinpoint scars and the raw material cannot be used for full grain leather. Raw materials affected by tick-infection are therefore down-graded and are of reduced value to the leather industry.

Another important skin condition due to ecto-parasite is caused by Mange or scab. This is a skin disease, which is caused by various species of mites infesting domestic animals. The distribution of these ecto-parasites is almost universal. The parasites are minute, rounded or oval, short-legged, flat organisms, which are normally host-specific ${ }^{[6]}$.

\subsection{Abattoir Practices}

2.3.1. Homestead slaughter: Most of the small stock is slaughtered in homesteads and therefore this is scattered and periodic. Small stocks (goats and sheep) are mainly killed during festivities, either for religious purposes or wedding celebrations. The methods of slaughter and conditions vary widely not only from homestead to homestead but also the practice in different countries. For instance, in the Sudan the flaying methods employed in abattoirs is pulling of skins instead of flaying with knife practiced in other countries. Pulling reduce incidence of flay cuts as the skins are pulled off the carcass The different methods of slaughter reflect directly on the quality of raw skins obtained with the pulled skins having less slaughter defects and therefore fetching a better price. This slaughter method however cannot be applied on cattle at this level due to physical limitations, as the animals are large.

2.3.2. Rural slaughter slabs: Most livestock slaughtered in rural slaughter slabs is done under very poor conditions. While goats and sheep are slaughtered mainly in homesteads, cattle in many countries are slaughtered in poorly equipped slaughter points where the infrastructure is sometimes a slab of concrete, under a tree or using poles for hoisting carcasses. These facilities are normally located adjacent to butcheries in various trading centres. The slaughtering therefore takes place in scattered areas and often without adequate supervision.

The tools used in these facilities or in homesteads are usually rudimentary and cause damage to the hides and skins during slaughter. In many cases running water is not available and hides are not washed 
off after slaughter. More often than not lifting blocks for raising carcasses are not available and therefore all operations are carried out on the floor ${ }^{[6]}$.

2.3.3. Mechanised abattoirs/slaughter houses: Poor flaying, lack of skills and absence of for instance hide pullers in modern abattoirs lead to production of low quality hides and skins. The post slaughter handling of raw materials exacerbates the prevailing bad situation. The following defects on hides are directly caused by slaughter and post slaughter operations.

2.3.4. Rubbed grain: This damage is produced by dragging the unflayed carcass over rough and uneven ground and can even be caused by rough concrete. The grain is generally rubbed off or 'frizzed' and is a definite cause of loss in value to the tanner. Preventative measures can be adopted in the field or slaughterhouses. Stout poles could be used to raise the carcass off the ground or the carcass could be supported on poles, which are then dragged along. Slaughterhouses should have smooth floors where the animal is flayed which eliminate or reduce trauma caused by dragging. Bad pattern: This is caused by indiscriminate ripping. 'Ripping' being the initial opening cuts down the centre of the belly and the four legs. The correct method of ripping ensures a uniform pattern, with bellies of equal width, well opened shanks and dewlap, a round butt and adequate tails ${ }^{[14]}$.

2.3.5. Flay cuts, scores or gouges: This damage is caused by the careless use of the knife or by the use of unsuitable knives. Flay cuts constitute the most serious mechanical defects on hides and skins. Lack of proper tools like the rounded flaying knives, lack of flaying skills and carelessness lead to loss of quality or outright rejection of raw hides and skins.

2.3.6. Causes and Impacts of Post-Slaughter Defects on Quality: Post-Slaughter activities such as curing, storage, packaging and transportation if not properly executed according to standards and best practices could lead to defects such as;

2.3.7. Grain cracks: After flaying and curing according to standard practice the hides and skins are properly fold with the grain tugged before they dry up. Broken fibres on the grain side of hides and skins that were dried folding causes grain cracks and distortion of shapes ${ }^{[10]}$. Grain cracks produces leather with lower breaking strength and looser structures.

2.3.8. Bacterial damage: Bacterial and enzymatic breakdown, rots hides and skins if not timely and properly cured. Hides and skins should be preserved within a short period of time after flaying to avoid bacterial growth and decomposition. This downgrades the quality of the hides and skin. Putrefaction affects both the grain and flesh sides resulting in hair slip and in advance stage complete disintegration of the corium. Exposing the cured hides and skins to water or rain in the process of storage and transportation could also lead to bacterial damage ${ }^{[11]}$.

2.3.9. Mechanical damage: This defect is caused by tools and machines mishandling resulting in cuts, holes and poor shapes. Poor pattern cutting before flaying distort the shape and affects the optimal utilization of leather during leather products production. It also reduces the finished leather grade. The careless use of knife or unsuitable tools during flaying leads to cuts and also over stretching the hides and skins during hoisting causes distortions and holes if not properly managed.

2.3.10. Poor bleeding/Veininess: If the carcass was not properly bled-out at the time of slaughtering, blood remains in the vessels and capillaries of the hides and skins encouraging rapid bacteria growth and visibility of the veins on the grain side of the leather. Such leather is not suitable for suede production. Veininess is well-known in goat skin and more prominent in glazed kid leather ${ }^{[12]}$. 
Other defects are caused by contamination and insect infestation due to poor handling during storage and transportation damaging the hides and skins and reducing the quality of the finished leather.

\subsection{Relative Importance of Factors Affecting Quality:}

2.4.1. Reduces prices and exports quality of products: Defects on hides and skins caused by pre/postslaughter activities downgrades the quality of finished leather and products there diminishing their market value there reducing the global market competiveness.

2.4.2. Limits available of raw materials to boost the productivity of leather industries:The effects of such defects often leads to decrease in breaking strength, distortion of shape and waste of raw materials during pattern cutting and as rejects. This reduces optimization of raw materials and low productivity.

2.4.3. Encourages sales and consumptions of hides and skins as ponmo: Some parts of Nigeria especially the South-West consumes hides and skins as a special delicacy which is detrimental to health and the leather industry. Most of the hides and skins sold for consumption as ponmo are rejects from the abattoirs and tanning industries due to infections or some defects as earlier mentioned. In the process, some good quality hides and skins are sold out for consumption to satisfy the demands for this delicacy. This habit competes greatly with the scares raw materials available for the leather industries thereby reducing productivity.

\section{MATERIALS AND METHODOLOGY}

\subsection{Karu Abattoir}

Karu abattoir was established in 1997. The Abattoir is located behind the old Chief's Palace in Karu Village, Abuja-Federal Capital Territory Abuja (FCT). It is popularly known and referred to as Karu Abattoir.

The Federal Capital Territory Administration previously operated a major abattoir in Garki, and a minor one at Karu, Abuja. In 2005, the Garki abattoir was closed down and relocated to the present location (Karu). This was as a result of urbanisation and migration.

The abattoir was duely registered and certified by The Federal Capital Territory Administration (FCTA) with the initial capacity of; five (5) Personnel, twenty Butchers (20). It established to accommodate the slaughter of fifty (50) cattle and one hundred Sheep and goats daily.

Currently, the number of personnel has increased to twenty (20)-12 approved by government and 8 casual staff, one hundred and seventy (170) butchers on the average while 150-170 cattle and five hundred (500) sheep and goats are being slaughtered averagely on daily bases.

NOTE: The number of animals slaughtered is dependent on the season of the year.

3.1.1. Abattoir Requirements Fulfilment for the Site: The abattoir though located in a boundary town is presently in the middle of a busy part of the town which houses residential areas, schools and various business outfits in both the FCT and Nasarawa State and the road network leading to and from the abattoir is accessible and in good state. More so, borehole supply of water to the abattoir is effective. Their source of Power supply is from the Abuja Electricity Distribution Company (AEDC), the abattoir also operates a generating set in events of power failure.

In addition to these, varied sources of labour ranging from butchers, transporters, cleaners, security personnel, etc., are very much available, a livestock market is also situated close to the abattoir. It is also necessary to note that a nearby stream serves as a drainage channel for the abattoir. 
The following standard required facilities are present in the in Karu Abattoir; the hoisting facility, a room for condemned meat and offal, veterinary laboratory and an emergency slaughter room.

3.1.2. Meat, Hides and Skin Inspections: The post- mortem examination on Meat, Hides and Skin are carried out in the abattoir by the Staff of the Federal Capital Authority (FCTA). The personnel responsible for this are; veterinary staff (DVM) and Para-veterinary staff/Animal health staff (HND, OND).

The disease records are majorly; Tuberculosis and Fasciolosis in cattle, Taeniasis in sheep and goats. Others are contagious bovine pleuro-pneumonia, and Paramphistomiasis.

3.1.3. Waste Disposal System: The ingesta are burnt in an incinerator while effluents are channelled to the nearby stream via drainage partway.

\subsection{NOTA-BENNE:}

a soak-away pit originally collects the effluent (from the previous plan i.e. mini-abattoir plan) but following the increase in slaughter, the pit could no longer hold the effluent.

3.2.1. By-Product Utilization: The Bones are burnt and sold to farmers, Hides and Skins are cured and taken to Kano and then sold on request to the Tanneries. The Horns and Hooves are taken to Lagos for export purposes and Blood is collected by a few people for further processing.

\section{RESULT AND DISCUSSION}

\subsection{The Administration Hierarchy in the Karu Abattoir}

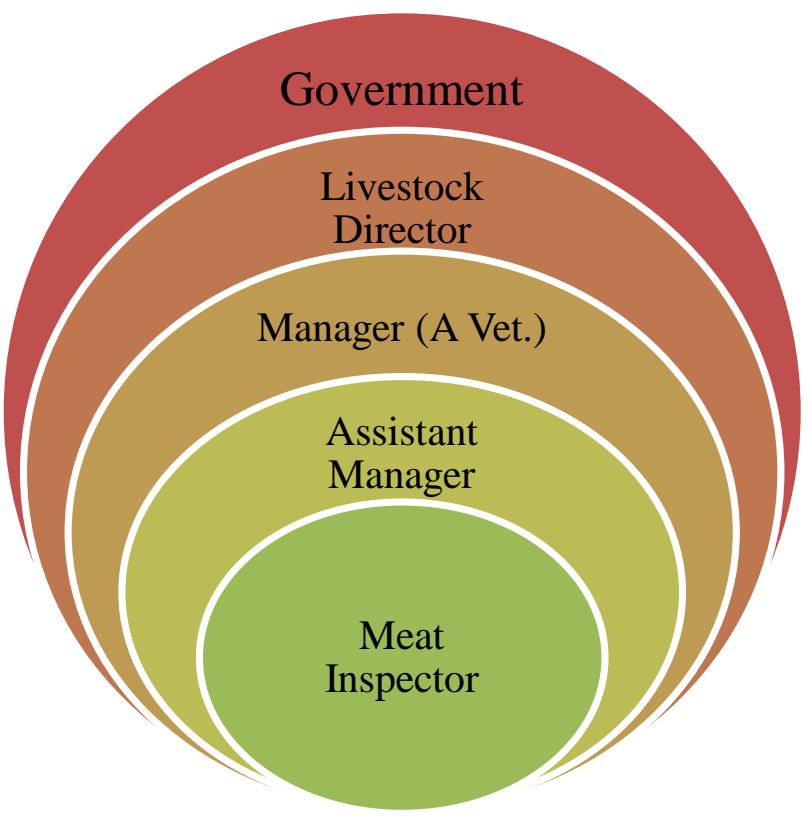

4.2. Sources of Information: All information here upon our visit to the Abattoir, were provided by the Manager and staff of the abattoir who granted us access on our introduction as a Student of the Veterinary Public Health and Preventive Medicine, Ahmadu Bello University, Zaria, and as staff of 
Nigerian Institute of Leather and Science Technology. under the purview of the Federal Ministry of Science and Technology.

\subsection{Pictures Taken at the Site:}

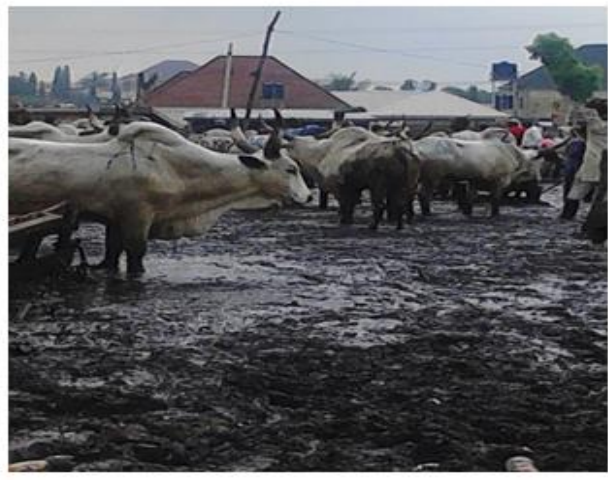

(a)

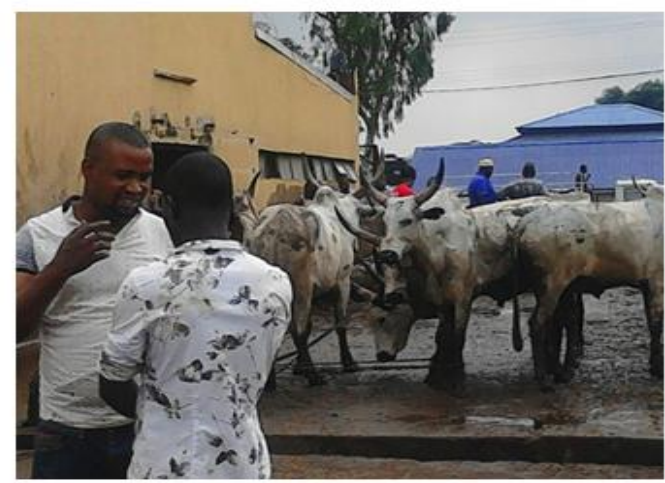

(b)

Plate 1 (a \& b): The Lairage outside the Slaughter Hall

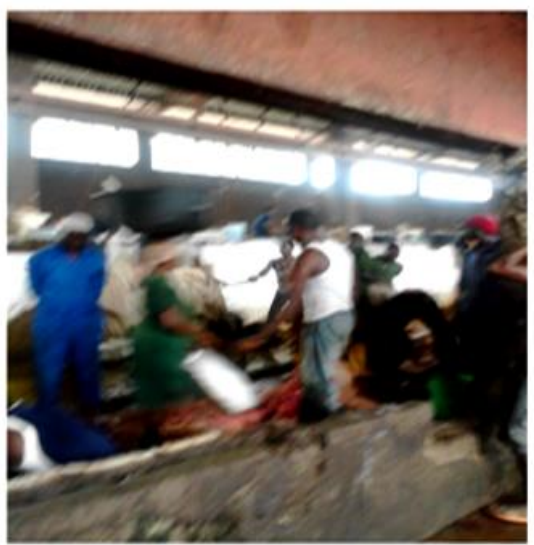

(c)

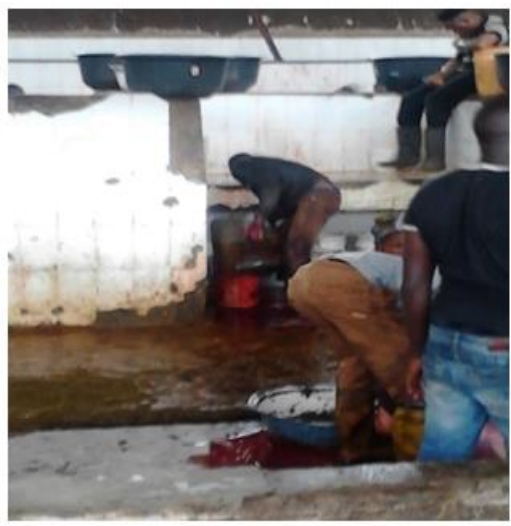

(d)

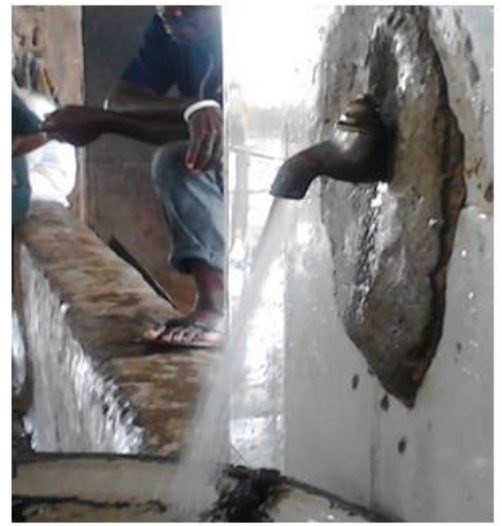

(e)

Plate 2: (c, d, \& e): The Slaughter Hall

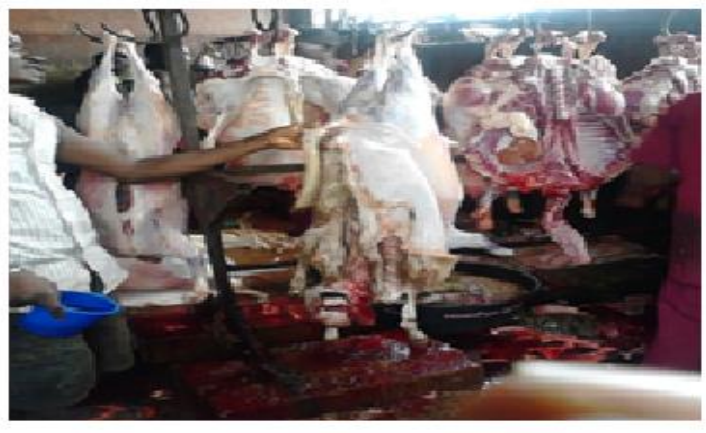

Plate 3 (f): Sheep and Goat Flaying Section

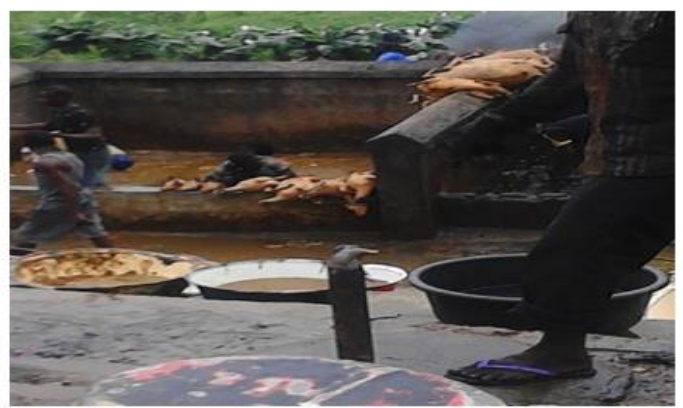

Plate 4 (g): Goats and Sheep Being Processed After Slaughter 

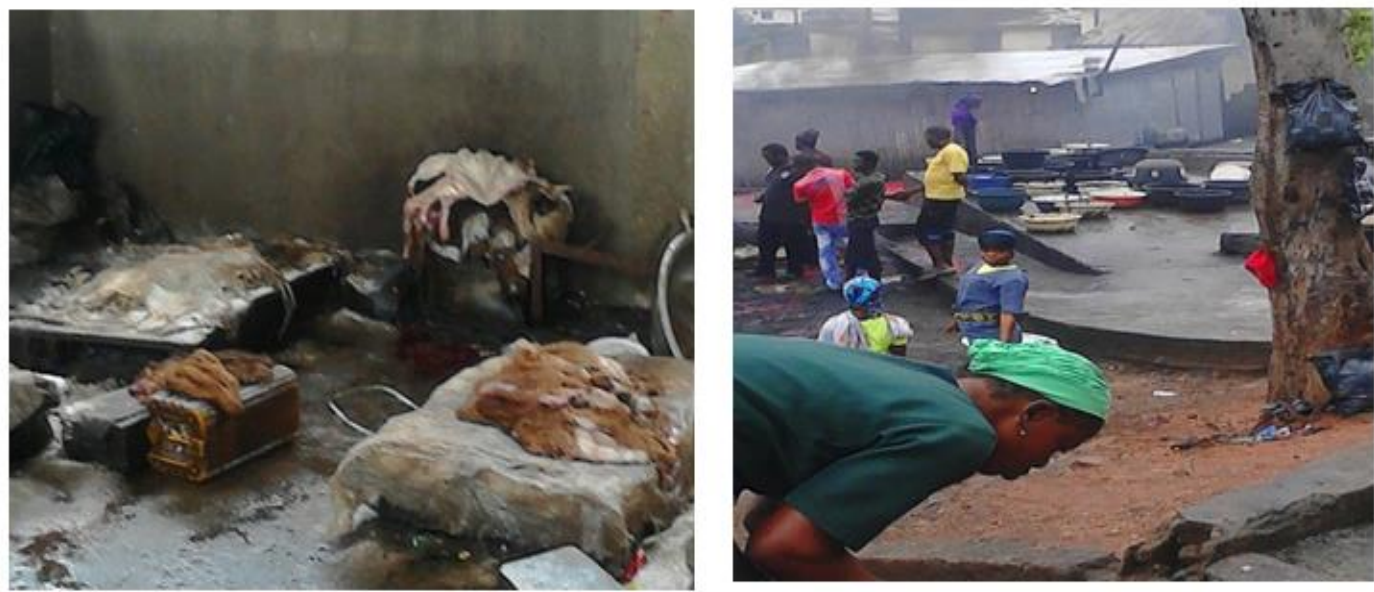

Plate 5 (h): Hides and Skin Curing Section

Plate 6 (i): A Soak-Away Pit (Originally Used for Effluent Disposal)
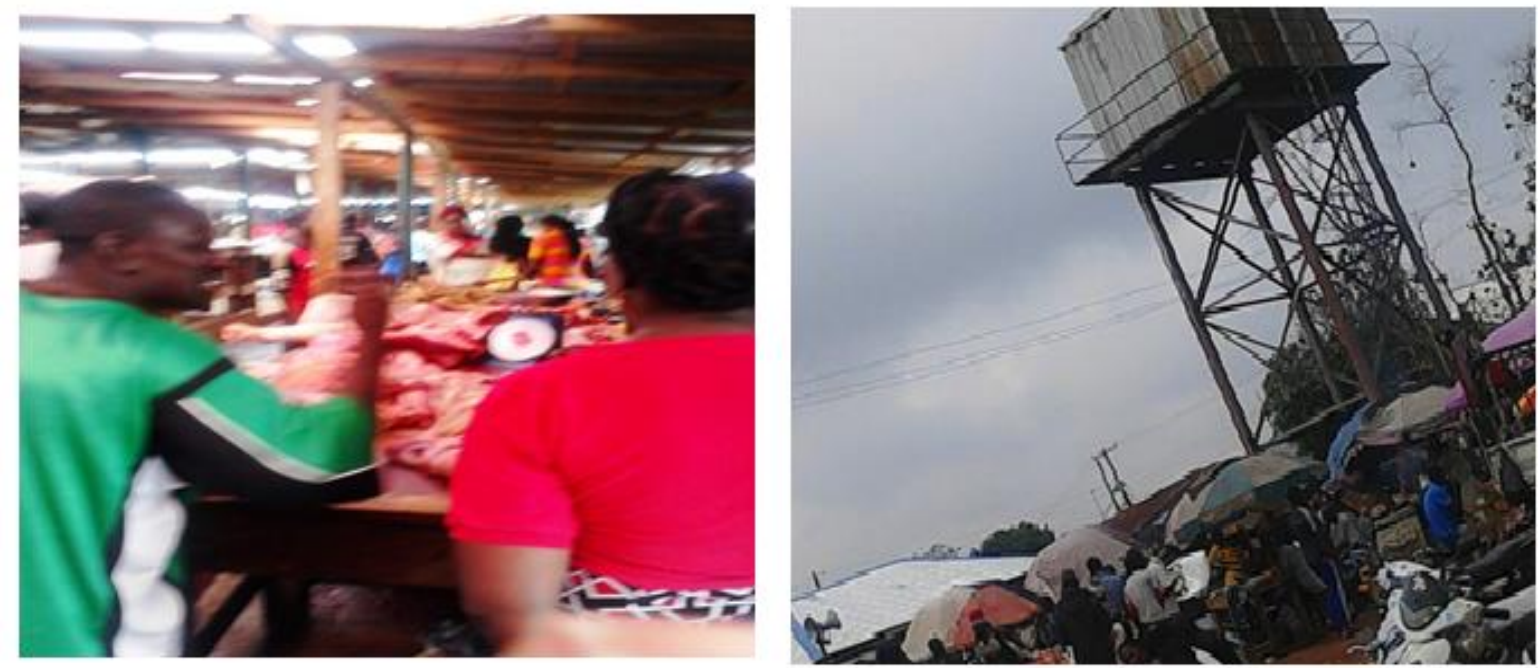

Plate 7 (j): Meat Market Close-By

Plate 8 (k): Water Tank
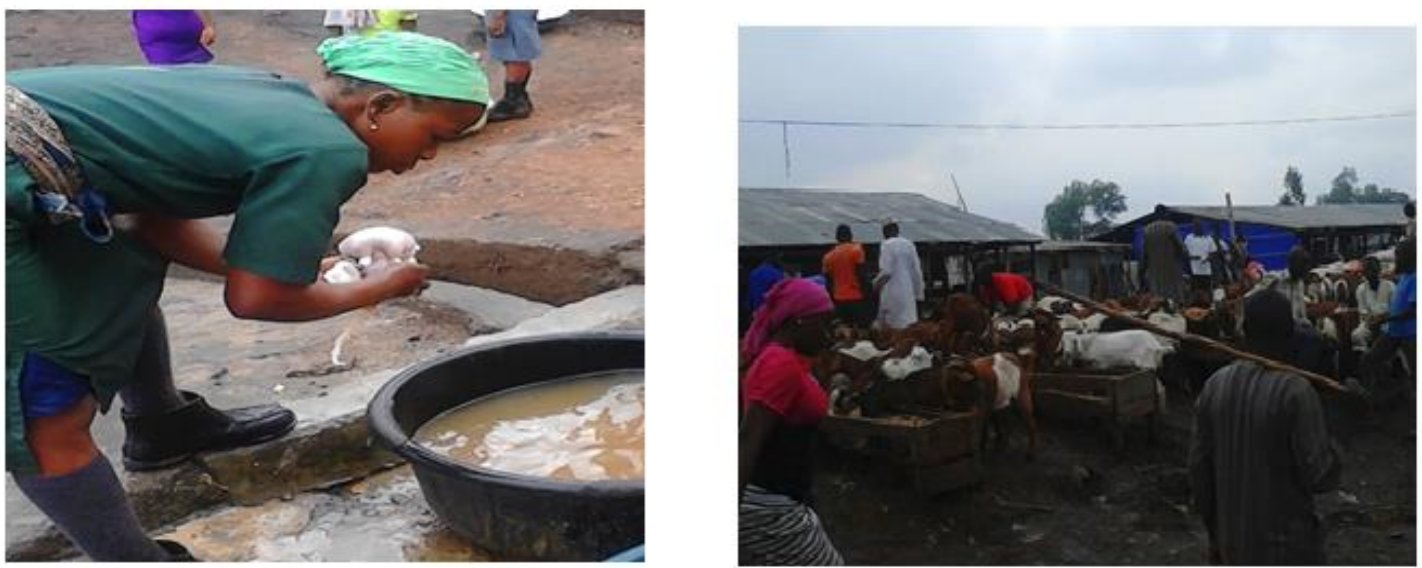

Plate 9 (I): A Casual Worker

Plate 10 (m): A Livestock Market Near-By 

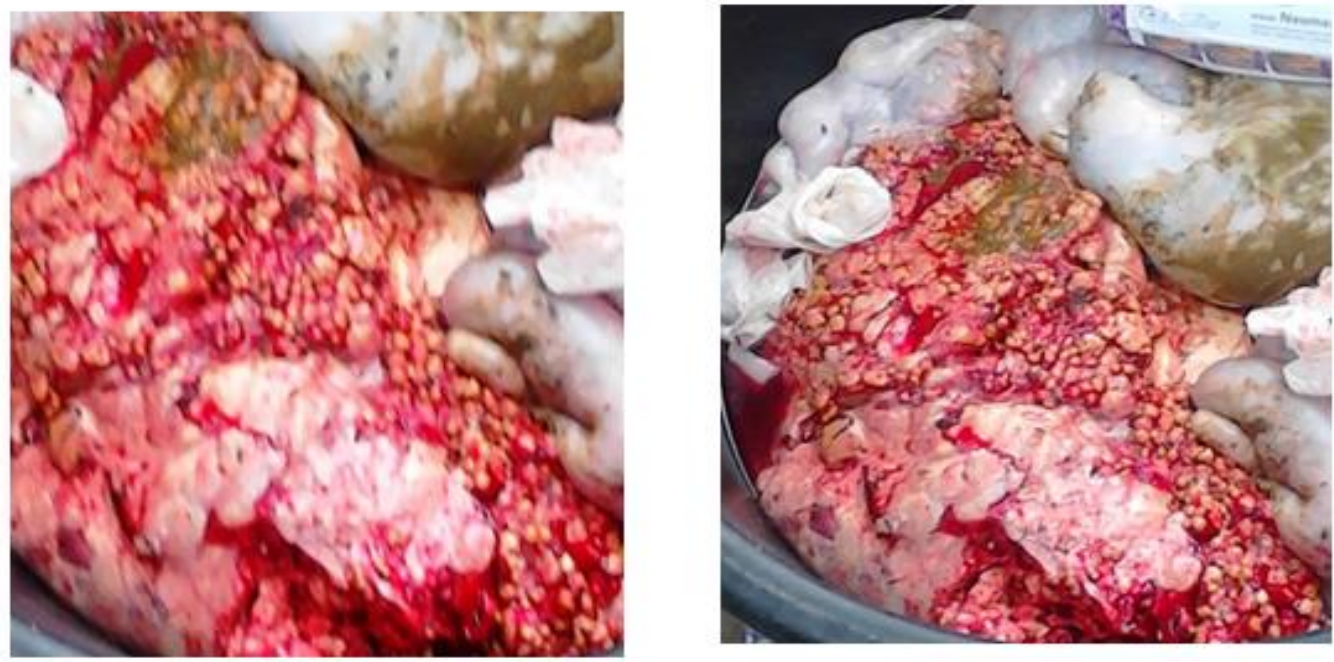

Plate 11 (n): Condemned Offals

Plate 12 (p): Condemned Lungs with $\mathrm{Tb}$ Lesions, Foetuses

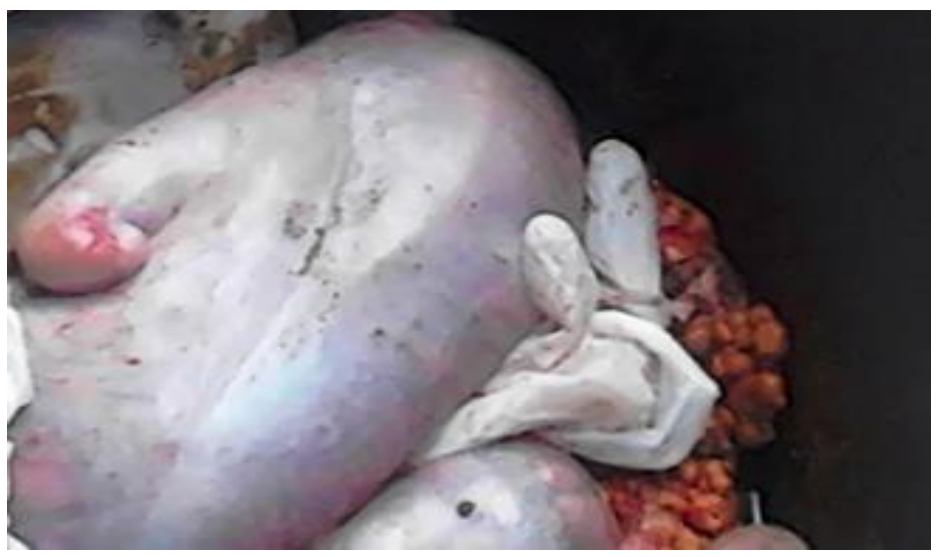

Plate 13 (q): Condemned Offals (Lungs with Tuberculosis Lesions)

\subsection{OBSERVATIONS}

1. Flies and offensive odour were minimal. Upon enquiry, it was gathered that:

- the premise was fumigated daily (putting Hazard Analysis Critical Control Point, HACCP into consideration),

- Sources of maggots and odour are identified and arrested using de-odorizing agents and readily available chemicals.

2. The site lack proper sanitation and hygiene standards were not properly adhered to.

3. Handling, proper preservation and drainage to manage waste water were also a challenge.

4. The site lacks proper waste disposal and management system.

5. Workers were not properly kitted with boots, aprons, hand gloves and scarf.

6. The facilities are over ultilised due to increase in population and hence demands. 


\subsection{RECOMMENDATIONS}

The Federal Capital Territory Administration should;

1. Provide adequate source of waste collection point for treatment before discharge into the nearby stream to protect the public health.

2. A functional pulley equipment to ensure adequate recovery of sheep and goat skin to avoid damage.

3. Expansion of the hides and skin preservation room and to deploy advanced hides and skins preservation system to keep the products in good state during transportation and before tanning.

4. Establishment of standard abattoirs in each of the area councils in Abuja municipal to minimise over flooding of the facility and ensure proper harvesting of hides and skins for the leather industry.

5. enforcing policies that will ensure compliance to standards

\section{REFERENCES}

1. G.A. Eisnitz, Slaughterhouse: The Shocking Story of Greed, Neglect and Inhumane Treatment Inside the U.S. Meat Industy. Prometheus Books, 1997.

2. CAC (Codex Alimentarius Commission). Hazard Analysis and Critical Control Point (HACCP)-System and Guidelines for Its Application. Codex Alimentarius Commission CAC/RCP1-1969, Rev. 3, Rome,1997a.

3. CAC (Codex Alimentarius Commission). Recommended International Code of Practice General Principle of Food Hygiene. Codex Alimentarius Commission CAC/RCP1-1969, Rev. 3, Rome, 1997b.

4. TAS (Thai Agricultural Standard), Good Manufacturing Practices for Abattoir. National Bureau of Agricultural Commodity and Food Standards, Ministry of Agriculture and Cooperatives. Thai Agricultural Standard (9004-2004), Bangkok. Published in the Royal Gazette, 2005, Vol.122 Special Section 64D

5. Abattoir Law ((Law no. 114, August 1, 1953) as of December 27, 2007) www.mhlw.go.jp>foodsafety.

6. M.A. Jabbar, S. Kiruthu, B. Gebremedhin, S. Ehui, Essential Actions to Meet Quality Requirements of Hides, Skins and Semi-Processed Leather from Africa. A Report prepared for the Common Fund for Commodities Amsterdam. Nitherland, 2002.

7. S.M. Kiruthu, R. O’Shaughessy, T. Masuku, Y. Awale, L.L. Paya, T. McCallin, A. Mwasyoge, Assessment for the Development of the Hides and Skins, Leather and Leather Products Sector in Bostswana. Draft Report to the United Nations Industrial Development Organisation. Gaborone, Botswana.2000, Pp5.8

8. S.L. Naporos, Factors Influencing the Quality of Hides and Skins, A Case of Kajido Country of Kenya. MSc. Thesis, University of Nairobi. 2012, DOI:https:// www.intracen.org/uploaded files/Kenya\%20Leather\%20Investment\% 20Profile \%203-1_web.pdf 
9. A. Husen, A. Tilahun, A. Teshale, T. Gashaw, Review on Pre and Post-Slaughter Defeats on Hides and Skins in Ethopia. Advances in Biological Research. 2016, 10 (3): 154-161. ISSN 1992-0067.

10. G.U. Bisrat, Defect Assessment of Ethiopian Hides and Skins: The Case of Tannariesin Addis Ababa and Modjo, Ethiopia. Global Veterinaria, 2013, 11(4): 455-461.

11. B. Amde, Major Factors Affecting Hide and Skin Production, Quality and the Tanning Industry in Ethopia. Advances in Biological Research, 2017,-11(3): 116-125. ISSN 1992-0067.

12. I. Mann, Rural Tanning Techniques Food and Agricultural Organisation 1960. Pp: 15-19.

13. A.B.H. Abaker, Impact of Some Defects in Sudanese Sheep and Goats Skins on Leather Quality. MSc. Thesis, University of Khartoum, 2007. DOI: khartoumspace.uofk.edu>handle

* Corresponding Author : Onukak, I.E.

Nigerian Institute of Leather and Science Technology, Zaria, Nigeria

Online date of publication: 18.02.2021 